\title{
Modelling changes in paralytic shellfish toxin content of dinoflagellates in response to nitrogen and phosphorus supply
}

\author{
Eurgain H. John, Kevin J. Flynn* \\ Ecology Research Unit, School of Biological Sciences, University of Wales Swansea, Singleton Park, Swansea SA2 8PP, \\ Wales, UK
}

\begin{abstract}
A dynamic mathematical model is presented for the growth and Paralytic Shellfish Poison (PSP) content of Alexandrium fundyense. The model includes cellular nitrogen-cycling to enable the synthesis of toxins in the absence of an external nitrogen-source. PSP synthesis is promoted by phosphorus stress but depressed by nitrogen stress, with the model containing sigmoidal functions relating nitrogen and phosphorus status to toxin synthesis. The model was tuned simultaneously to 4 sets of experimental data for ammonium- and nitrate-grown cultures of A. fundyense that were P-replete or P-stressed. The good fit of the model, with a single set of control constants, to almost all data (cellular N:C and P:C, cell size, chlorophyll a:carbon, toxin content, external nutrients) demonstrates the capabilities of mechanistic models under dynamic situations. The potential consequences of recycling toxin-N, or of not making toxins at all, were considered using the model. Loss of toxin from cells could be by turnover or by leakage/excretion; model output and experimental data sets suggest that turnover may be the fate in P-stressed nitrate-grown cells but not in ammoniumgrown cells. From simulations, there appears to be no significant disadvantage in expending nitrogen on toxin synthesis, thus there need not be a specific evolutionary advantage in the process. If PSP synthesis were selection-neutral this could explain the significant diversity in PSP synthesis capabilities within the genus Alexandrium.
\end{abstract}

KEY WORDS: Alexandrium fundeyense $\cdot$ Dinoflagellate $\cdot$ PSP toxins $\cdot$ Mechanistic model $\cdot$ Nutrient status

\section{INTRODUCTION}

Understanding processes that lead to the growth of toxic dinoflagellates and subsequent contamination of shellfish is of major importance for aquaculture. Here we employ a model to promote our understanding of the production of paralytic shellfish poisons (PSPs) by the dinoflagellate genus Alexandrium. While construction of models often indicates areas where knowledge is lacking, operation of models, on the other hand, can be used to explore implications for algal physiology and algal succession. The recent works of Liu et al.

${ }^{*}$ Corresponding author. E-mail: k.j.flynn@swansea.ac.uk
$(2001 \mathrm{a}, \mathrm{b})$ are examples pertaining to the ecophysiology of dinoflagellates. For toxic species there is the issue of the role of toxins in physiology and the implications for selection pressure; why do some strains of only a few species synthesise toxins, and in those that do why is the level of synthesis so variable? Amongst the suggestions made for the procession of toxins are that toxins may act as a deterrent against predation (see review by Turner et al. 1998) and that they act as nutrient-storage compounds synthesised when the nutrient supply is imbalanced (Boyer et al. 1987, Cembella 1998).

This work is directed primarily towards modelling the genus Alexandrium. The construction of the model is described below, making reference to previously 
developed models of algal physiology (Flynn et al. 1997, Flynn 2001), but requires some knowledge of PSPs. To summarise briefly, PSPs are a suite of 22 cyclic nitrogenous compounds of molecular weight between ca 291 and 400 (Shimizu 1996). They are synthesised, using amino acid precursors, by certain strains of a few genera of dinoflagellates (Alexandrium and Gymnodinium; Cembella 1998) and by some bacteria (Gallacher et al. 1997, Doucette et al. 1998, Gallacher \& Smith 1999). Analogous compounds are synthesised by some cyanobacteria (Jones \& Negri 1997 , Plumley et al. 1999, Kaas \& Henriksen 2000). The toxin profile (i.e. the relative amount of different toxins) is relatively invariant within a dinoflagellate strain (Anderson et al. 1994, Flynn et al. 1996b, John \& Flynn 2000a), but the concentration (on a cell volume basis) varies significantly, as does the amount per cell (in part because cell size varies with nutrient status).

In general terms, nutrient stress (deficiency) initially results in changes in cell metabolism without affecting growth rate, and then becomes rate- and finally yieldlimiting (Flynn \& Flynn 1995). Phosphorus-stressed cells of Alexandrium spp. may contain more toxin because they are larger than other cells and also because phosphorus stress promotes toxin accumulation. PSP concentrations are lowest when nitrogen is the sole limiting nutrient and highest during the refeeding of nitrogen-starved cells and also when phosphorus is limiting (Boyer et al. 1987, Anderson et al. 1990a, Flynn et al. 1996a, Siu et al. 1997, Béchemin et al. 1999). John \& Flynn (2000a) report similar changes in toxin content with phosphorus plus nitrogen stress, with additional information on the fractionation of phosphorus within cells of $A$. fundyense. Toxin content is also lower in cells growing at high light and using nitrate rather than ammonium as the nitrogen-source (Ogata et al. 1987, Flynn et al. 1996b, John \& Flynn 2000a).

\section{Alternative strategies for model construction for toxin synthesis and loss}

The handling of toxin synthesis within mechanistic models of algal physiology is problematic. While net changes in toxin content are known, knowledge of the underlying gross rates of change due to synthesis and loss, and of the mechanistic bases, is weak. Thus, cessation of net toxin synthesis could be because gross synthesis stops (e.g. repression brought about by endproduct regulation or a lack of precursor compounds) and/or because processes leading to the loss of toxin become more important (giving a dynamic regulation). While the literature makes reference to the synthesis of toxins (e.g. Shimizu et al. 1985, Plumley 1997, Taron-
cher-Oldenburg et al. 1997), the fate of toxins is not discussed in detail; they could be broken down within the cell, released, or just diluted within the cell by successive cell divisions.

\section{Toxin synthesis}

Synthesis requires the availability of a source of nitrogen (e.g. Flynn et al. 1996a), and of light, but is fastest in low rather than high light (e.g. Ogata et al. 1987 ) i.e. it is promoted by high availability of nitrogenous metabolites with relatively low availability of carbon. From experimental results (Anderson et al. 1990a, John \& Flynn 2000a) it is clear that toxins may be synthesised using nitrogen that is recycled within the cell, rather than solely using inorganic nitrogen recently taken into the cell. This raises questions about the rate of cell-N turnover that must provide nitrogen for toxin synthesis under these conditions. However, data for these turnover rates are lacking. What we do know is that dinoflagellates have relatively high respiration rates, typically equivalent to around one-third of gross photosynthesis rates (Harris 1978), and that respiration and the operation of biosynthetic processes are closely coupled in all organisms.

Phosphorus stress could promote toxicity by 2 obvious routes. There is some evidence that the concentrations of intracellular free amino acids increase during phosphorus stress (Anderson et al. 1990a, and for nitrate-grown cells only John \& Flynn 2000a). This could lead to an increase in the concentration of precursors for toxin synthesis, or otherwise enhance synthesis by raising the nitrogen status of the cells at the level of low molecular weight metabolites. Phosphorus stress could also adversely affect any end-product repression of synthesis, thus allowing synthesis to continue to a higher level than normal. Oshima (1995a) reports the role of ATP-dependent enzymes for the interconversion of some PSP toxins; hence the phosphorus status may be expected to affect the toxin profile.

\section{Loss of toxins}

The regulation of toxin content must explain how toxin per cell can decline, for example during nitrogen stress (Anderson et al. 1990a, Flynn 1998a). Such a decline could simply be passive through a dilution of toxin amongst new cells during cell division, or by a real fall in total cellular toxin by leakage from the cells or through toxin degradation. The former must occur, albeit slowly, but it is affected by the implications of cell enlargement with phosphorus stress (hence toxin per cell may increase or stay constant while toxin per unit $\mathrm{C}$ 
may remain stable or fall). A real loss can clearly also occur as the cellular toxin per millilitre culture falls (e.g. John \& Flynn 2000a). However, the critical question is whether or not toxin- $\mathrm{N}$ is actually lost from the cells. At least within nitrogen-stressed cells (which logic would dictate would acclimate to retain nitrogen), one may argue for a recycling of toxin- $\mathrm{N}$ rather than a leakage from the cell.

\section{Implementation of mechanisms within the model}

After exploring various mechanisms in model structure (developed from Flynn 1998a), including making half-saturation constants for toxin synthesis and/or turnover a function of phosphorus status, and linking the phosphorus status to the rate of toxin turnover, the solution that was found most consistent with data in the literature was as follows.

Synthesis is made a positive function of nitrogen status, with light an absolute requirement (new products of photosynthesis appear to be required for toxin synthesis). The rate of toxin synthesis is also negatively related to phosphorus status (i.e. high synthesis with low status). Toxin turnover is simply made a half-life function of the cellular concentration; this route was taken following an analysis of experimental data for

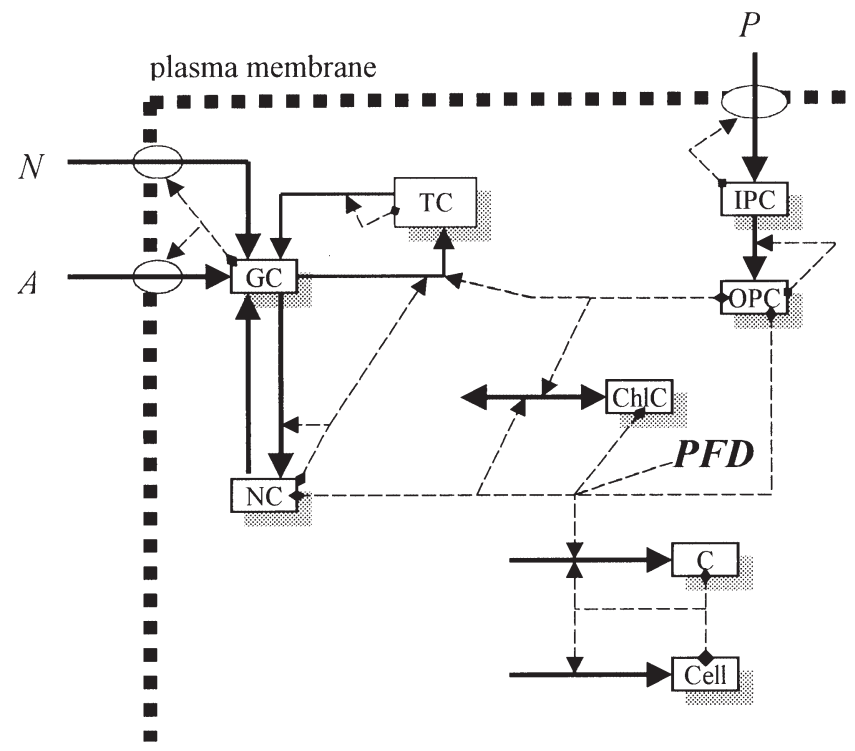

Fig. 1. Schematic of model structure showing the major flows in and out of state variables (continuous arrows and boxes) from the external parameters (nutrients and light), and the major feedback processes (dashed arrows). A: ammonium; C: C-biomass; Cell: cell density; ChlC: chlorophyll C quota; GC: glutamine C quota; IPC: cellular inorganic PC quota; $\mathrm{N}$ : nitrate; NC: cellular NC quota; OPC: cellular organic PC quota; P: phosphate; PFD: photon flux density; TC: toxin-N C quota; other details in Table 2 the disappearance of cellular toxin which gave no strong evidence for an alternative strategy such as a hyperbolic loss related to cellular toxin concentrations or to nutrient status. In the model toxin- $\mathrm{N}$ recycles; the implications of the loss of toxins from the cell are considered in the 'Results'. The respiratory cost of toxin synthesis is assumed to be similar to that for all other nitrogenous components in the cell (costed at $1.5 \mathrm{gC}$ $\mathrm{g} \mathrm{N}^{-1}$ : see Flynn 2001).

\section{THE MODEL}

Most of the features of the construction of the model have been described elsewhere (Flynn et al. 1997, Flynn \& Flynn 1998, John \& Flynn 2000b). The model was developed from that described by Flynn (2001), with deletion of the iron and silicon modules and replacement of the cell division component by a form that can simulate diel cell division. John \& Flynn (2000b) considered the need for a detailed modelling of phosphorus dynamics involving internal phosphorus pools, and concluded that for most purposes wholeorganism phosphorus, or at most reference to the internal inorganic and organic phosphorus pools (for which we have data; John \& Flynn 2000a), is adequate.

The full model is available from K.J.F. or from http://www.swan.ac.uk/biosci/research/kjf.htm. Here we describe only the functions specific to toxin synthesis and to the dinoflagellate, making reference to the schematic in Fig. 1 and to Tables 1, $2 \& 3 . \mathrm{NCu}$ and $\mathrm{PCu}$ are quotients describing, respectively, the nitrogen and phosphorus status of the cells. The general form for this normalised quota function for Nutrient $\mathrm{X}$ is given in Eq. (1), with a quotient of 0 indicating a poor status and 1 an optimal status:

$$
\mathrm{XCu}=\frac{(\mathrm{XC}-\mathrm{XCo})}{(\mathrm{XC}-\mathrm{XCo}+\mathrm{XCk})} \cdot \frac{(\mathrm{XCm}-\mathrm{XCo}+\mathrm{XCk})}{\mathrm{XCm}-\mathrm{XCo}}
$$

where $\mathrm{XC}$ is the mass ratio, or quota, of atomic constituent $\mathrm{X}$ to $\mathrm{C}, \mathrm{XCo}$ and $\mathrm{XCm}$ are the minimum and maximum quotas, and $\mathrm{XCk}$ is a constant that affects the shape of the relationship between $\mathrm{XC}$ and the resultant quotient $\mathrm{XCu}$.

The quota relationships for N:C and P:C were determined (Fig. 2A) using data from experiments conducted under conditions described in John \& Flynn (2000a), with values for nitrogen and phosphorus maximum (NCm, PCm) and minimum (NCo, PCo) quotas and for the constants (NCk, PCk) given in Table 1. These normalised quotas are combined to give the quotient $\mathrm{NPCu}$, controlling the interaction between nitrogen and phosphorus stress. This combination has been achieved through Eq. (2) (discussed further in 
Flynn 2001), giving a quotient value that is part way between the threshold combination (where $\mathrm{NPCu}$ takes the minimum value of $\mathrm{NCu}$ and $\mathrm{PCu}$ ) and the multiplicative combination (where $\mathrm{NPCu}$ is the product of $\mathrm{NCu}$ and $\mathrm{PCu}$ ):

$$
\begin{aligned}
\mathrm{NPCu}= & \{\mathrm{NCu}>\mathrm{PCu}\} \cdot[\mathrm{PCu} \cdot(1-\mathrm{PCu}+\mathrm{PCu} \cdot \mathrm{NCu})] \\
& +\{\mathrm{NCu} \leq \mathrm{PCu}\} \cdot[\mathrm{NCu} \cdot(1-\mathrm{NCu}+\mathrm{PCu} \cdot \mathrm{NCu})]
\end{aligned}
$$

The constants for defining the transport of ammonium and nitrate in relationship to the $\mathrm{N}: \mathrm{C}$ status of the cells were derived experimentally for Alexandrium fundyense (Fig. 2B) using methods described in Flynn et al. (1999). The half-saturation constants for ammonium AKt and nitrate NKt transport were estimated at $0.93 \pm 0.13$ and $0.94 \pm 0.19 \mu \mathrm{M}$ respectively from experimental data of E. H. J. (unpubl.) using methods discussed in Flynn (1998b); we have set them both at $1 \mu \mathrm{M}$ in the model. Nitrogen then enters the glutamine pool (GC), from whence it is used to further synthesise all other nitrogenous components (NC), including toxins (TC) (Fig. 1).

Our models have not hitherto included internal nitrogen-cycling. Nitrogen-cycling occurs in all cells as proteins (especially functional forms such as enzymes rather than structural forms) become damaged or need

\begin{tabular}{|c|c|c|c|c|}
\hline Constant & Description & Value & Unit & Source \\
\hline A1 & & -1.0834 & $\mathrm{gNgC}^{-1}$ & Tuned (i.e. parameterised) \\
\hline A2 & Constants for relationship between & 2.14 & - & Flynn et al. (1999); present Fig. 2b \\
\hline A3 & $\mathrm{N}: \mathrm{C}$ and ammonium transport & -2.2585 & - & Flynn et al. (1999); present Fig. 2b \\
\hline A4 & & 5.61 & $\operatorname{gC~g~N}^{-1}$ & Flynn et al. (1999); present Fig. 2b \\
\hline AAmG & $K_{\mathrm{m}}$ for NC synthesis & 0.001 & $\operatorname{gNgC}^{-1}$ & Flynn 2001 \\
\hline Alpha & Chlorophyll-specific slope for photosynthesis & $12 \times 10^{-6}$ & $\begin{array}{l}\left(\mathrm{m}^{2} \mathrm{~g} \mathrm{chl} \mathrm{a}^{-1}\right) \\
\left(\mathrm{gC} \mu \mathrm{mol} \text { photon }^{-1}\right)\end{array}$ & Tuned \\
\hline AKt & $\begin{array}{l}\text { Half-saturation constant for ammonium } \\
\text { transport }\end{array}$ & 14 & $\mu g \mathrm{~N}^{-1}$ & Experimental (see 'The model') \\
\hline Ccello & Minimum C content per cell & 1.315 & $\mathrm{ng} \mathrm{C}$ cell $^{-1}$ & Tuned \\
\hline ChlCD & Quotient for decay of chlorophyll C & 0.09119 & - & Tuned \\
\hline Kts & Constant for toxin synthesis & 0.053765 & - & Tuned \\
\hline N1 & & -0.4443 & $\operatorname{gNgC}^{-1}$ & Tuned \\
\hline N2 & Constants for relationship between & 1.2274 & - & Flynn et al. (1999); present Fig. 2b \\
\hline N3 & $\mathrm{N}: \mathrm{C}$ and nitrate transport & -1.6767 & - & Flynn et al. (1999); present Fig. 2b \\
\hline N4 & & 5.83 & $\operatorname{gC~g~N}^{-1}$ & Flynn et al. (1999); present Fig. 2b \\
\hline NCD & Turnover of NC & 0.3465 & $d^{-1}$ & See 'The model' \\
\hline $\mathrm{NCk}$ & Constant for $\mathrm{N}$ control over growth & 0.15 & $\operatorname{gNgC^{-1}}$ & Experimental (Fig. 2a) \\
\hline $\mathrm{NCm}$ & Maximum N:C & 0.165 & $\operatorname{gNgC}^{-1}$ & Experimental (Fig. 2a) \\
\hline $\mathrm{NCo}$ & Minimum N:C & 0.057 & $\mathrm{gNgC}^{-1}$ & Experimental (Fig. 2a) \\
\hline NKt & $K_{\mathrm{m}}$ for nitrate transport & 14 & $\mu g \mathrm{~N}^{-1}$ & Experimental (see 'The model') \\
\hline Pcello & Minimum P content per cell & 11.0 & $\operatorname{pg} \mathrm{P}$ cell $^{-1}$ & Tuned \\
\hline $\mathrm{PCk}$ & Constant for P control over growth & 0.006 & $\mathrm{gP} \mathrm{gC}^{-1}$ & Experimental (Fig. 2a) \\
\hline $\mathrm{PCm}$ & Maximum P:C & 0.02352 & $\mathrm{gP} \mathrm{g} \mathrm{C}^{-1}$ & Experimental (Fig. 2a) \\
\hline PCo & Minimum P:C & 0.0047 & $\mathrm{gP} \mathrm{g} \mathrm{C}^{-1}$ & Experimental (Fig. 2a) \\
\hline PCuM & Scalar for toxin synthesis & 12.3068 & - & Tuned \\
\hline $\mathrm{PCuP}$ & Power constant for toxin synthesis & 4.22138 & - & Tuned \\
\hline PKt & $K_{\mathrm{m}}$ for phosphorus transport & 62.0 & $\mu g \mathrm{P}^{-1}$ & Tuned \\
\hline $\mathrm{TCk}$ & Constant for control of toxin synthesis & 0.01295 & - & Tuned \\
\hline TCP & Power constant for toxin synthesis & 2.44489 & - & Tuned \\
\hline TCsR & Scalar for rate of toxin synthesis & 0.00357 & $\operatorname{gNgC}^{-1}$ & Tuned \\
\hline Tta & Scalar for toxin turnover & 5.71708 & - & Tuned \\
\hline Um & Maximum growth rate & 0.47376 & $d^{-1}$ & Tuned \\
\hline
\end{tabular}

Table 1. Constants. $K_{\mathrm{m}}$ : half-saturation constant; -: dimensionless. (See Flynn 2001) 
to be removed as part of biochemical regulation. The simplest way to incorporate nitrogen-cycling is to install a link from NC (cellular organic nitrogen, excluding glutamine) back to ammonium or to the glutamine pool. The latter is more suitable (if less realistic) because it enables the use of a simplified model structure by omission of the internal ammonium pool. We have used a function that assumes a half-life of functional nitrogenous material (i.e. $\mathrm{NC}$ excluding $\mathrm{NCo}$,
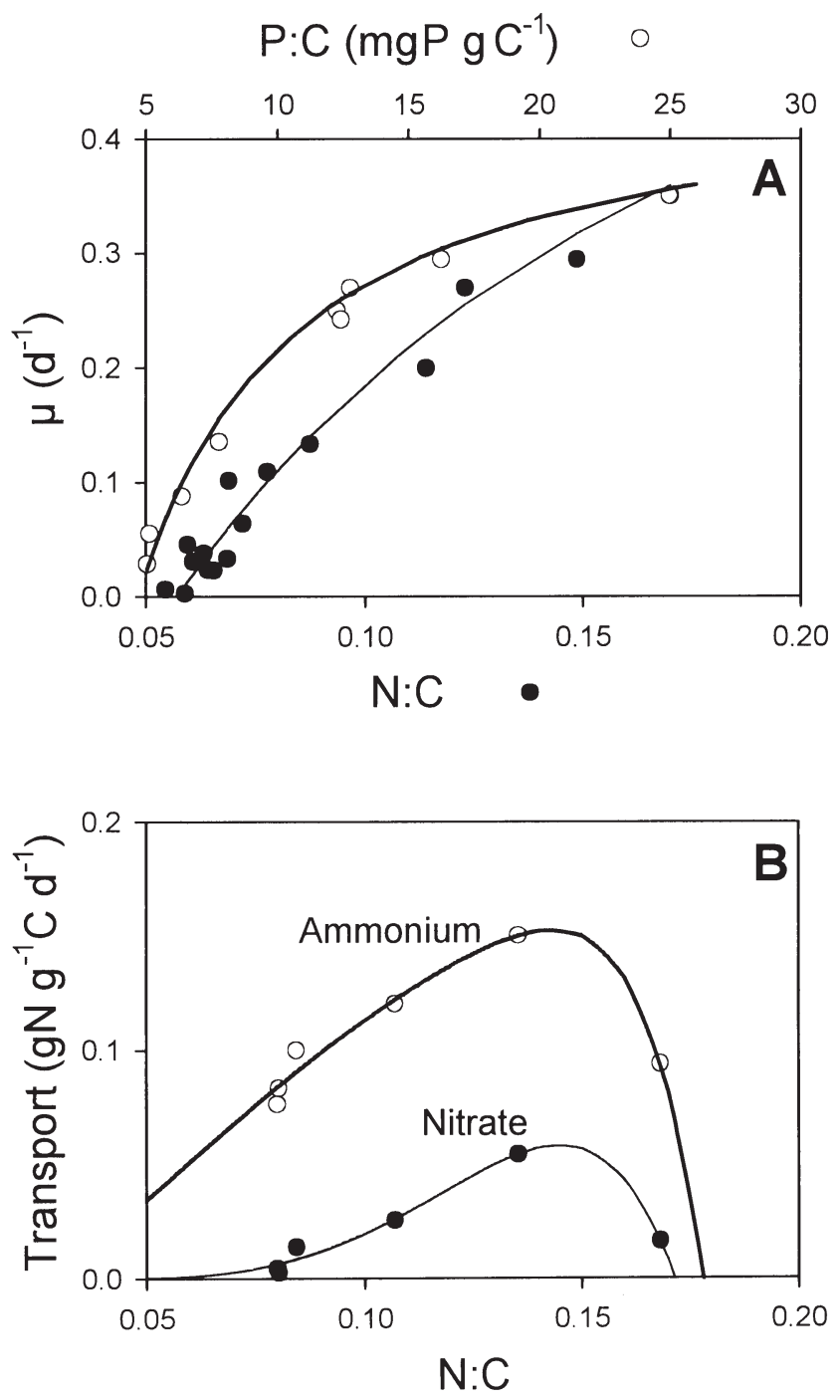

Fig. 2. Alexandrium fundyense. Relations between $\mathrm{N}: \mathrm{C}$ and $\mathrm{P}: \mathrm{C}$ quotas and growth rates (A), and between the $\mathrm{N}: \mathrm{C}$ quota and the initial transport rate of ammonium and nitrate (B). Symbols represent experimentally derived data points, while the curves represent the functional relationships used with the model. The equation describing the curves for transport, $\mathrm{Xtq}$, of Nutrient $\mathrm{X}$ is

$$
\mathrm{Xtq}=\{1 / \mathrm{NC}>\mathrm{X} 4\} \cdot \mathrm{Um} \cdot \mathrm{X} 1 \cdot\left(1-\mathrm{e}^{\mathrm{X} 2 \cdot(1 / \mathrm{NC}-\mathrm{X} 4)}\right) \cdot \mathrm{e}^{\mathrm{X} 3 \cdot(1 / \mathrm{NC}-\mathrm{X} 4)} ;
$$

Constants $\mathrm{X} 1 \ldots \mathrm{X} 4$ are given (as $\mathrm{A} 1 \ldots \mathrm{A} 2$ and $\mathrm{N} 1 \ldots \mathrm{N} 4$, for ammonium or nitrate respectively) in Table 1 the minimum quota) of $2 \mathrm{~d}$. The precise value is not critical because the (gross) rate of synthesis of NC is enhanced to counter the turnover so that the net rate of synthesis is the same. An important consequence of a high turnover is, however, enhanced respiration associated with synthesis of NC. Using the rate of turnover stated above, the respiration rate amounts to around $30 \%$ of concurrent gross photosynthesis, a value in line with the expected rate for dinoflagellates (Harris 1978).

The maximum rate of synthesis of amino and nucleic acids in support of NC, AAsm (Eq. 3), runs at twice the net requirement for nitrogen. This rate is normally set in the model as the product of the maximum values for growth rate $(\mathrm{Um})$ and $\mathrm{N}: \mathrm{C}(\mathrm{NCm})$. To counter the rate of decay of $\mathrm{NC}$, the gross synthesis rate is now scaled to Um plus the decay constant NCD rather than just Um as in our previous models (Flynn et al. 1997). This is modified by the quotient $\mathrm{NCu}$, describing the nitrogen status (1 is good, 0 is poor: Eq. 1); hence the rate of synthesis is maximal when the cell has a high nitrogen status.

$$
\mathrm{AAsm}=2(\mathrm{Um}+\mathrm{NCD}) \cdot \mathrm{NCm} \cdot \mathrm{NCu}
$$

Input of nitrogen from GC into NC (Eq. 4) is scaled by AAsm, regulated by a quotient for the availability of surplus carbohydrate in the dark (CAAs, see Flynn et al. 1997), and is a hyperbolic function of the size of GC. While that part is the same as used in our previous models, the model structure also now incorporates a decay function $[(\mathrm{NC}-\mathrm{NCo}) \cdot \mathrm{NCD}]$ returning nitrogen from $\mathrm{NC}$ to $\mathrm{GC}$ as a function of the level of excess of $\mathrm{NC}$ over the minimum quota NCo and of NCD. This enables the synthesis of toxin (TC) from recycled nitrogen. The value of NCD employed, $0.3465 \mathrm{~d}^{-1}$, gives a half-life of non-essential nitrogenous compounds of $2 \mathrm{~d}$. The final term in Eq. (4) is a correction for changes in $\mathrm{N}$ : $\mathrm{C}$ with changes in $\mathrm{C}$-growth rate:

$$
\begin{aligned}
\frac{\mathrm{d}}{\mathrm{d} t} \cdot \mathrm{NC}= & \text { AAsm } \cdot \frac{\mathrm{GC}}{(\mathrm{GC}+\mathrm{AAmG})} \cdot \mathrm{CAAs} \\
& -(\mathrm{NC}-\mathrm{NCo}) \cdot \mathrm{NCD}-\mathrm{NC} \cdot \mathrm{Cu}
\end{aligned}
$$

In the model we refer to toxin content as the sum of all PSP toxins, quantified in terms of toxin-N. We do this because the toxin profile, and hence the toxicity per toxin- $\mathrm{N}$ for a given strain (and for that simulated here) is relatively invariant (but see 'Discussion'). The rate of toxin synthesis (Eq. 5) is scaled to Um and by a constant (TCsR) setting the rate when cellular $\mathrm{P}$ is in excess. The rate of synthesis is further modified by a power function related to the phosphorus status of the cell through the quotient $\mathrm{PCu}$, taking a value of 1 if P-replete and 0 if P-deplete (Eq. 1). The value of the constant PCuP affects the sensitivity of the enhancement of toxin synthesis in response to changes in $\mathrm{P}$ stress, while constant PCuM defines the maximum in- 
creased rate of synthesis. The values of these constants together exert considerable leverage over the interaction between phosphorus status and toxin synthesis.

$$
\mathrm{TCsrt}=\mathrm{TCsR} \cdot \mathrm{Um} \cdot\left(1+\mathrm{PCuM} \cdot \frac{(1-\mathrm{PCu})^{\mathrm{PCuP}}}{(1-\mathrm{PCu})^{\mathrm{PCuP}}+\mathrm{Kts}}\right)
$$

The shape of this function is shown in Fig. 3a, using the constant values obtained from tuning the model to experimental data (see end of this section).

The value of toxin-N per $\mathrm{C}$, TC, can only increase in the light, as defined by the Boolean logic term at the start of Eq. (6). Synthesis is then a sigmoidal function of the relative rate of amino acid synthesis (AAs relative to the maximum AAsm). This gives an index of the relative availability of low molecular weight nitrogen metabolites that may contribute to toxin synthesis. The inclusion of $\mathrm{NCu}$ (the quotient for nitrogen status) in
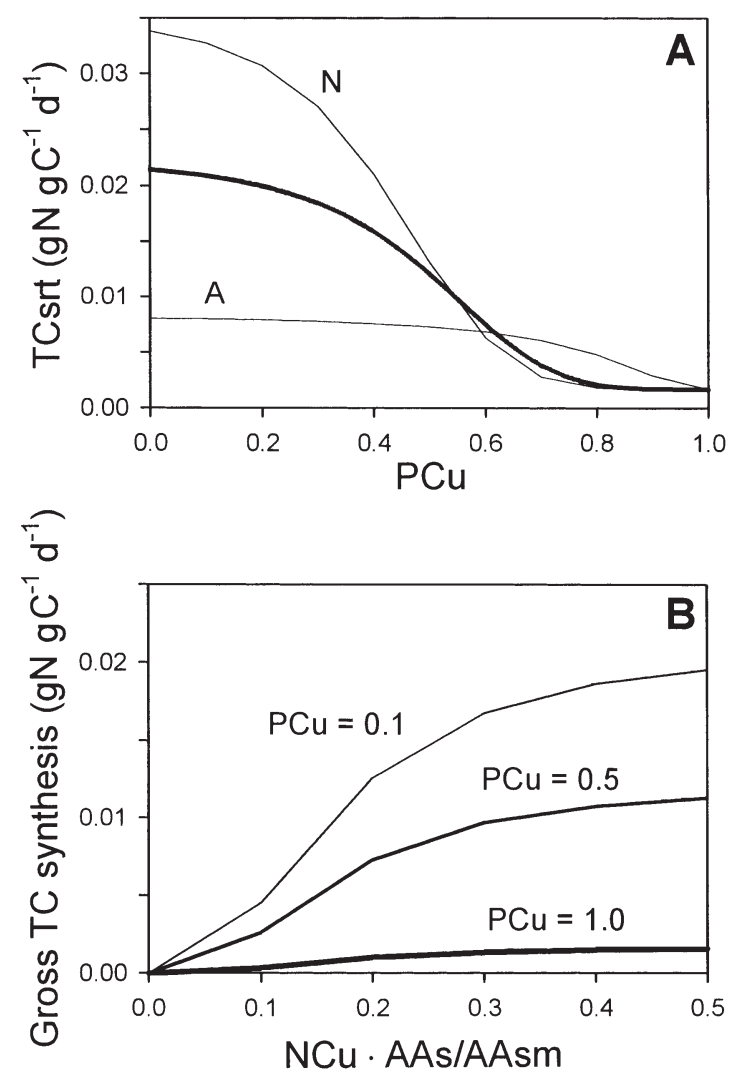

Fig. 3. (A) Relationship (bold curve) between the normalised $\mathrm{P}: \mathrm{C}$ quota $(\mathrm{PCu})$ and the maximum rate of toxin synthesis (TCsrt) when the model was tuned to data from all 4 nutrient regimes; when the model was tuned to all the phosphorusreplete data plus either the phosphorus-deplete ammoniumgrown culture (Relationship A) or the phosphorus-deplete nitrate-grown culture (Relationship N), the curve differed. (B) Selected values of PCu showing the relationship between the nitrogen status of the cell (given as a function of the normalised $\mathrm{N}: \mathrm{C}$ quota, $\mathrm{NCu}$, and the relative rate of amino acid synthesis, AAs/AAsm) and the gross rate of toxin (TC) synthesis this function results in a rapid decline in toxin synthesis with declining nitrogen status. TCk and TCP are constants for the sigmoidal function (within square brackets in Eq. 6) controlling this process with Tta a scalar for toxin turnover (the form of this function coupled with TCsrt is shown in Fig. 3B):

$$
\begin{aligned}
\frac{\mathrm{d}}{\mathrm{d} t} \cdot \mathrm{TC}= & \{\mathrm{PFD}>0\} \cdot \mathrm{TCsrt} \cdot\left[\frac{\left(\frac{\mathrm{NCu} \cdot \mathrm{AAs}}{\mathrm{AAsm}}\right)^{\mathrm{TCP}}}{\left(\frac{\mathrm{NCu} \cdot \mathrm{AAs}}{\mathrm{AAsm}}\right)^{\mathrm{TCP}}+\mathrm{TCk}}\right] \\
& -\frac{\mathrm{Um} \cdot \mathrm{TC}}{\mathrm{Tta}}-\mathrm{TC} \cdot \mathrm{Cu}
\end{aligned}
$$

To summarise, during exponential nutrient-replete growth (when $\mathrm{NCu}$ and $\mathrm{PCu}$ are both near 1, and AAs/AAsm is near 0.5) the gross synthesis rate of TC is near TCsR - Um. If only nitrogen is limiting, $\mathrm{NCu}$ falls towards 0 , and the value of the sigmoidal component of Eq. (6) does likewise; the rate of toxin synthesis thus decreases significantly. However, if phosphorus is also limiting, the increase in TCsrt (Eq. 5; see Fig. 3A) overrides the fall in the sigmoidal quotient so that toxin synthesis increases unless the nitrogen status (and hence $\mathrm{NCu}$ ) is very low. This interaction is shown with different $\mathrm{PCu}$ values in Fig. 3B. Decline in $\mathrm{TC}$ is a simple half-life function scaled to Um, while the final term in Eq. (6) corrects TC for changes in C-growth rate.

Processes of phosphorus nutrition and photoacclimation are as described previously (Flynn \& Flynn 1998, John \& Flynn 2000b, Flynn 2001). Cell division, which only occurs during the first part of the dark phase of the light:dark cycle, is controlled as follows: The rate of division, described by the state variable Div, is computed as a $4 \mathrm{~d}$ moving average, which better simulates growth of an asynchronous culture. NPCu describes the nitrogen phosphorus status of the cells (1 is good, 0 is poor; Eq. 2).

$$
\frac{\mathrm{d}}{\mathrm{d} t} \cdot \operatorname{Div}=\frac{\mathrm{NPCu} \cdot \mathrm{Um}-\mathrm{Div}}{4}
$$

The increase in cell numbers is controlled by a series of Boolean terms in Eq. (8). Division only occurs between day times (FRAC[TIME]) of 0.6 and 0.85 (light phase runs between 0 and $0.5 \mathrm{~d}$, division thus occurring during the early dark phase) and can then only occur if cells contain sufficient $\mathrm{C}$ (Ccell exceeds twice the minimum, Ccello) and sufficient $\mathrm{P}$ (Pcell exceeds twice the minimum, Pcello). If those conditions are all met then, during the appointed period, which lasts for $1 / 4$ of a day, cells increase by the value of Div 4 :

$\frac{\mathrm{d}}{\mathrm{d} t} \cdot$ cell $=($ FRAC $[$ TIME $]<0.85) \cdot($ FRAC $[$ TIME $]>0.6)$ 
The model was parameterised (tuned) against experimentally derived data for Alexandrium fundyense using a genetic algorithm as supported by Powersim Solver v2 (Powersim AG, Norway). Four data series were chosen (LN1, LN5, LA1 and LA5 in John \& Flynn 2000a) for batch growth using either nitrate or ammonium, with these cultures either being nitrogen-limiting (termed phosphorus-replete) or nitrogen-phosphorous co-limiting (termed phosphorus-deplete) respectively. The data used for tuning were external nutrients, cellular $\mathrm{N}: \mathrm{C}$, $\mathrm{P}: \mathrm{C}$, chlorophyll a:C, and toxin-N:C, and C:cell. The constants tuned were those indicated in Table 1 . Tuning against all 4 experimental data series was performed simultaneously using an arrayed model of 4 populations with common constants. The fits of the model output to individual data sets for individual parameters thus represent a compromise.

\section{RESULTS}

\section{Fit of the model to experimental data}

Judging the adequacy of model outputs to data is non-trivial (Haefner 1996, Rykiel 1996). The quality of fits may be judged on the dynamics (timing) as well as the magnitude of output values relative to real data. In an ideal world, however, output and data will be identical at all time points and a regression between them will return an $r^{2}$ of 1 . Here we initially used regressions of experimental data for Alexandrium fundyense against model output to test the model fit. Between 72 and $98 \%$ of the variation in the experimental data could be explained by model simulations for external nutrients, N:C, P:C, cell numbers, ChlC, TC and toxins, with no significant difference between the observed and predicted data $(p<0.005)$. Only for P:C for P-replete cells and for Ccell were $\mathrm{r}^{2}$ values non-significant; however there were no significant differences between observed and predicted means for these variables for ammonium- or nitrate-grown cultures (paired-sample $t$-test, $\mathrm{p}<0.001)$.

Overall the fit of the model to all 4 data sets was good (Figs 4 \& 5). It should be noted that the oscillations in the model output reflect responses to the $12: 12 \mathrm{~h}$ light:dark cycle. Each data point represents an average of at least 2 experimental measurements. It should be borne in mind that experimental work with dinoflagellates is complicated by low cell densities and the behaviour of the organisms, which leads to difficulties in obtaining homogeneous cell suspensions (over-vigorous mixing of the suspension kills cells) for sampling. There is thus a greater level of uncertainty for each data point than may be expected in experimental data for cultures of other phytoplankters. It is also apparent that there was a level of cell mortality in the cultures, especially for the P-deplete nitrate suspension (Fig. 5). For all of the experimental data sets (a total of 10: John \& Flynn 2000a)

Table 2. State variables for the model and external parameters (see also Fig. 1)

\begin{tabular}{|c|c|c|}
\hline $\begin{array}{l}\text { Variable/ } \\
\text { parameter }\end{array}$ & Description & Units \\
\hline \multicolumn{3}{|c|}{ State variables } \\
\hline $\mathrm{C}$ & C biomass & $\mu g \mathrm{Cl}^{-1}$ \\
\hline cell & Cell density & $10^{6}$ cells $^{-1}$ \\
\hline $\operatorname{chlC}$ & Chlorophyll C quota & $\mathrm{g} \mathrm{chl} \mathrm{g} \mathrm{C}^{-1}$ \\
\hline Div & $\begin{array}{l}4 \mathrm{~d} \text { moving average of cell } \\
\text { division rate }\end{array}$ & $d^{-1}$ \\
\hline GC & Glutamine C quota & $\mathrm{gN} \mathrm{gC}^{-1}$ \\
\hline IPC & Cellular inorganic PC quota & $\mathrm{gP} \mathrm{gC}^{-1}$ \\
\hline $\mathrm{NC}$ & Cellular NC quota & $\mathrm{gN} \mathrm{gC}^{-1}$ \\
\hline OPC & Cellular organic PC quota & $\mathrm{gP} \mathrm{gC}^{-1}$ \\
\hline $\mathrm{TC}$ & Toxin-NC quota & $\mathrm{gN} \mathrm{gC}^{-1}$ \\
\hline \multicolumn{3}{|c|}{ External parameters } \\
\hline A & Ammonium & $\mu g \mathrm{~N}^{-1}$ \\
\hline $\mathrm{N}$ & Nitrate & $\mu g \mathrm{~N} \mathrm{l}^{-1}$ \\
\hline $\mathrm{P}$ & Phosphate & $\mu g \mathrm{Pl}^{-1}$ \\
\hline PFD & Photon flux density & $\mu$ mol photon $\mathrm{m}^{-2} \mathrm{~d}^{-1}$ \\
\hline
\end{tabular}

Table 3. Auxiliary variables used in equations presented in this paper; -: dimensionless

\begin{tabular}{|c|c|c|}
\hline $\begin{array}{l}\text { Auxiliary } \\
\text { variable }\end{array}$ & Description & Units \\
\hline AAs & Rate of amino acid synthesis & $\mathrm{gNgC}^{-1} \mathrm{~d}^{-1}$ \\
\hline AAsm & Maximum rate of amino acid synthesis & $\operatorname{gNgC}^{-1} \mathrm{~d}^{-1}$ \\
\hline CAAs & $\begin{array}{l}\text { Quotient describing availability of carbohydrate } \\
\text { as a function of NC (see Flynn et al. 1997) }\end{array}$ & - \\
\hline Ccell & Carbon content of cell & $\mathrm{gC} \mathrm{cell}^{-1}$ \\
\hline $\mathrm{Cu}$ & Carbon-specific growth rate & $\mathrm{gC} \mathrm{gC}^{-1} \mathrm{~d}^{-1}$ \\
\hline $\mathrm{NCu}$ & Quotient describing N status & - \\
\hline $\mathrm{NPCu}$ & $\begin{array}{l}\text { Quotient describing the combined effects of } \\
\mathrm{N} \text { and P stress }\end{array}$ & - \\
\hline Pcell & Phosphorus content of cell & gP cell ${ }^{-1}$ \\
\hline $\mathrm{PCu}$ & Quotient describing P status & - \\
\hline TCsrt & $\begin{array}{l}\text { Rate of toxin synthesis, in terms of toxin-N } \\
\text { per carbon biomass }\end{array}$ & $g N \operatorname{gC}^{-1} \mathrm{~d}^{-1}$ \\
\hline
\end{tabular}


system-N and system-P declined, indicating a loss of organic material either through cell lysis and/or adherence of cells (notably resting stages or cysts) to the glassware.

The fit of the model to external nutrient data was good (Fig. 4), although phosphate in the P-deplete simulations fell more rapidly than the real data. The fit was improved if the value of PKq was made smaller than that indicated from the quota curve in Fig. 2a; however, we wished to show how the model performed when configured using experimentally derived constants. The use of a larger value of the half-saturation constant for phosphorus transport, PKt, also affected the timing of the exhaustion of phosphorus (not shown). The N:C simulations showed the correct dynamics, except that they responded more slowly than the real data for
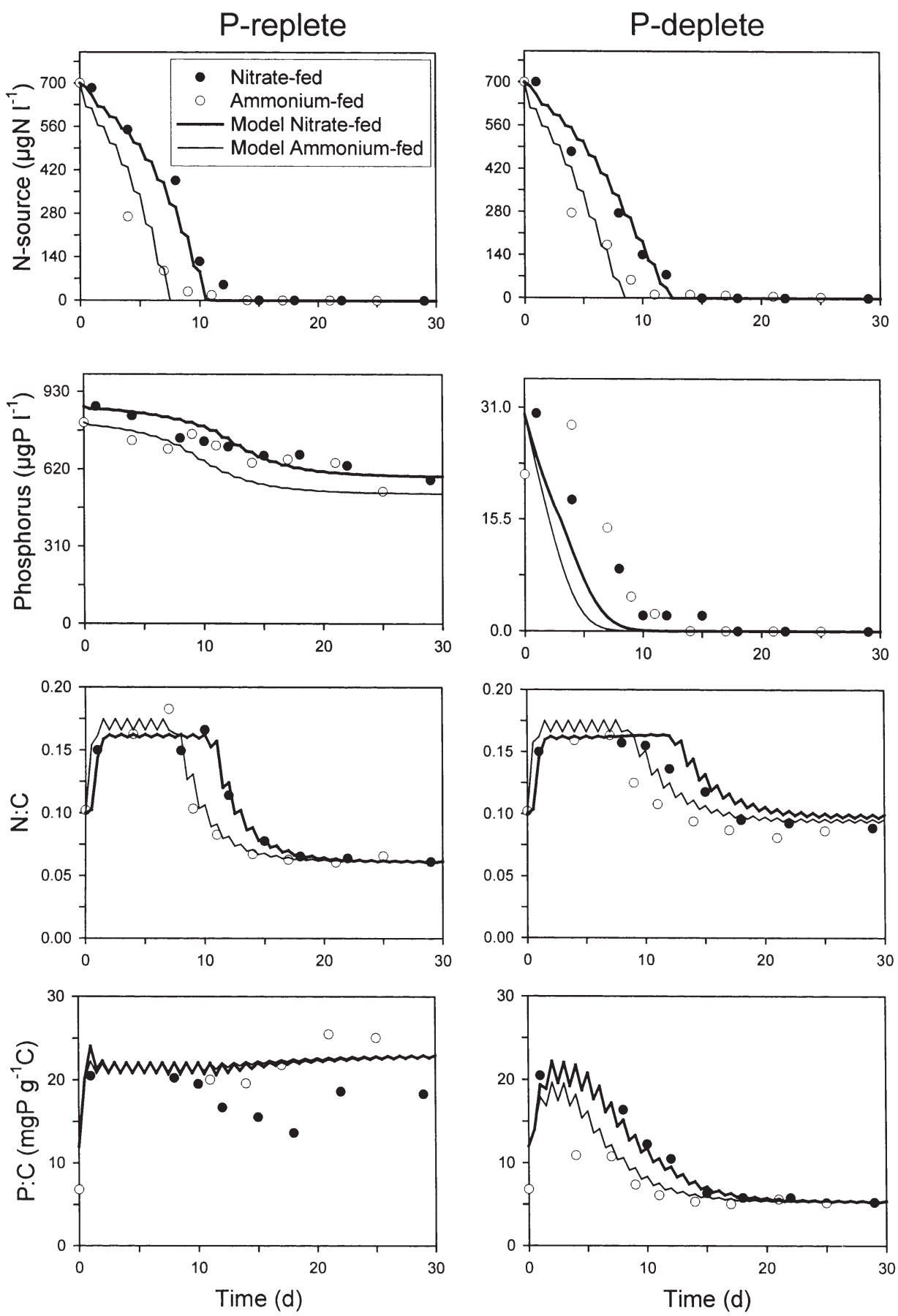

Fig. 4. Fits of the model (lines) to experimental data (symbols) for nitrogenous nutrients, external phosphorus, and the whole-cell quotas for $\mathrm{N}(\mathrm{N}: \mathrm{C})$ and $\mathrm{P}$ (P:C) from 4 culture systems 
P-deplete systems (Fig. 4). The fits against cellular P:C were also generally good (Fig. 4), especially given that, unlike $\mathrm{N}$ : $\mathrm{C}$, the $\mathrm{P}: \mathrm{C}$ ratio was obtained through 2 totally separate methodologies (oxidation of cell-P to $\mathrm{PO}_{4}{ }^{3-}$ and measurement using colorimetric assay versus elemental analysis for $\mathrm{N}$ and $\mathrm{C}$ ).

Although the model was not tuned to experimental data for cell numbers, the fits are presented here
(Fig. 5). The initial growth dynamics are correct in all instances, but the plateaux are too high for most and especially for the phosphorous-deplete nitrate-fed cells. This reflects the increasing loss of cells through lysis and/or adherence to the culture vessels as indicated by the fall in the measured system-N and system-P.

Simulations of changes in cell size, Ccell, appear quite reasonable for phosphorus-replete cells (Fig. 5),


Fig. 5. Fits of the model (lines) to experimental data (symbols) for cell density, cell mass in terms of $\mathrm{C}$, chlorophyll $\mathrm{C}$ quota, and the toxin-NC quotas from 4 culture systems. When the alternative curves for TCsrt (Fig. 3a) were used there was no significant difference in the P-replete simulations for toxins (TC), but the fit of the model in the P-deplete series was improved by the use of the appropriate curve for ammonium (A)- or nitrate $(\mathrm{N})$-grown cultures
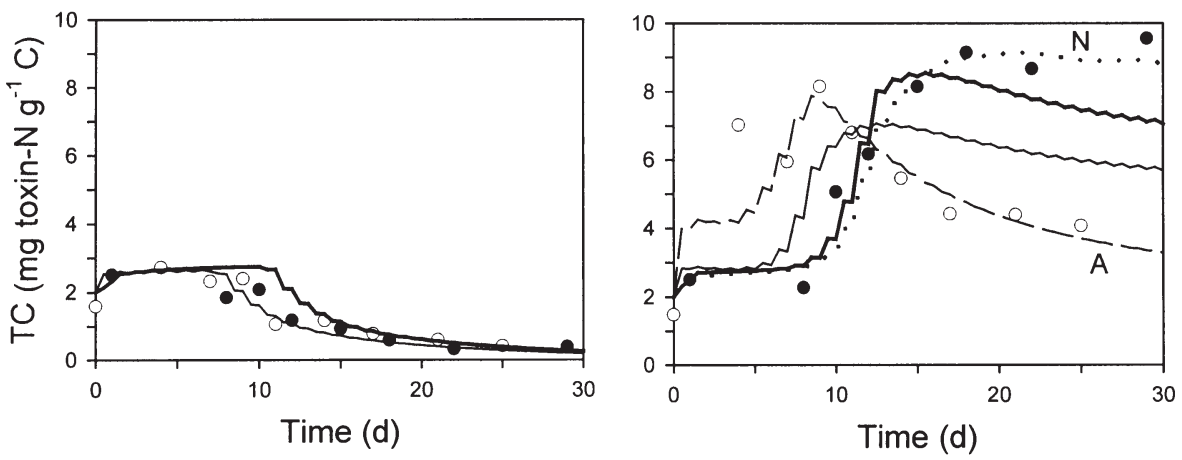
even though $\mathrm{r}^{2}$ indicated a non-significant relationship. For phosphorus-deplete cells, the experimental data are not so good, particularly during the stationary phase of growth: phosphorus-stressed cells in culture often show considerable variation in cell size, some of which may be attributable to sexual reproduction. Changes in pigmentation, chlorophyll C, were well simulated (Fig. 5).

Toxin content was simulated well for the phosphorus-replete suspensions (Fig. 5). However, there was dichotomy between the behaviour of phosphorusdeplete cells grown on ammonium versus nitrate. Ammonium-fed cells showed a more rapid rise in toxin content but then declined, while nitrate-fed cells retained a high toxin content into stationary phase. The simulation fit was tuned to these contrasting data sets and the result is (unsurprisingly) a compromise, although the general appearance more closely fits the nitrate data set. We shall return to this issue below. Toxin synthesis, expressed as toxin-specific 'growth' rate (as in Flynn et al. 1994 and Taroncher-Oldenburg et al. 1997) showed a rapid increase early in the light phase, a decline, and then an increase in the midlight phase. This pattern of simulated production (not shown) was thus similar to that determined experimentally by Taroncher-Oldenburg et al. (1997).

Overall, the model gives a good representation of the complex experimental data sets. The ability of the model to simulate both changes in $\mathrm{C}$ quota and cell size enabled it to reproduce changes in toxin content per C (Fig. 5) and per cell (Fig. 6). Deviations in model output reflect inadequacies in the model but also (at least to an equal level, one suspects) the facets of dinoflagellate behaviour and physiology that so complicate working with these organisms.

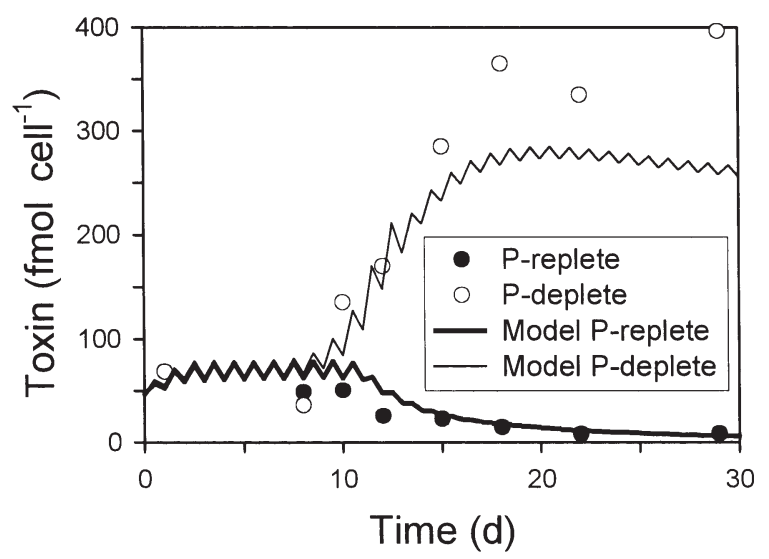

Fig. 6. Alexandrium fundyense. Experimental data plus simulations of toxin content per cell in nitrate-fed phosphorusreplete or phosphorus-deplete cells. Calculations assume 8 at of nitrogen per molecule toxin

\section{Toxin cycling and synthesis}

The simulations described above (shown in Figs 4 \& 5) used the model as described earlier in this paper. Having established that the model performs satisfactorily, we now consider the implications of the non-recycling of toxin-N. For this undertaking, the decay function of TC (Eq. 6) was redirected so the toxin was voided rather than re-entering GC. The instance where toxin synthesis does not occur at all was considered by setting constant TCsR to zero. Otherwise the model was not altered. The alternative structures were run in the same batch culture environment as employed before, or within a 'stretchbatch' system in which the batch culture was slowly diluted (here at a rate of $0.05 \mathrm{~d}^{-1}$ ) with fresh medium. There was no fundamental difference between the results from these culture scenarios; the batch systems equivalent to the nitrate series are shown here for comparison with the earlier plots (Fig. 7).

There was no significant difference in cell or carbon biomass yield between the outputs of the different model structures (e.g. Fig. 7). The only difference in cellular composition was for $\mathrm{N}$ : $\mathrm{C}$ in the low-phosphorus system (Fig. 7), where the non-toxic model was not so nitrogen-stressed, while the model that did not recycle toxin-N was most nitrogen-stressed (results that are wholly predictable). Between the toxic models (recycling versus non-recycling), there was no difference in toxin content (TC) in the phosphorus-replete simulations (not shown), but in the phosphorus-deplete condition toxin was lost more rapidly from the non-recycling model (Fig. 7). Note that this prediction more closely fits the loss of toxin (TC) from the phosphorusdeplete ammonium-fed cells shown in Fig. 5. An explanation for the difference in the toxin content of phosphorus-stressed nitrate versus ammonium-grown cells may thus lie in whether toxins are lost from the cells.

When considering the simulated level of toxin per volume of culture (rather than per unit carbon biomass), again there is no difference between the recycling and non-recycling phosphorus-replete scenarios (Fig. 8), with cellular toxin declining after Day 12 when the external nitrate is exhausted (cf. Fig. 4). However, while net toxin synthesis halts, gross synthesis continues. For the non-recycling model this leads to a gradual increase in extracellular toxin-N (phosphorusreplete data: Fig. 8). For the phosphorus-deplete scenario (Fig. 8), again the cellular toxin level in the non-recycling model declines and again the level of extracellular toxin- $\mathrm{N}$ rises, although to 3 times the level seen in the phosphorus-replete system. In the phosphorus-deplete system, the percentage of system$\mathrm{N}$ present as toxin-N amounts to $4 \%$ within cells, and 
$8 \%$ including any toxin- $\mathrm{N}$ released. The maximum amount of internal toxin-N in any simulation was $7.3 \%$ of total cellular $\mathrm{N}$.

\section{DISCUSSION}

\section{The model}

Overall, the model gives a good fit to experimental data for Alexandrium fundyense from 4 contrasting nutrient scenarios. This is the first published example of a comprehensive tuning of a complex multi-nutrient
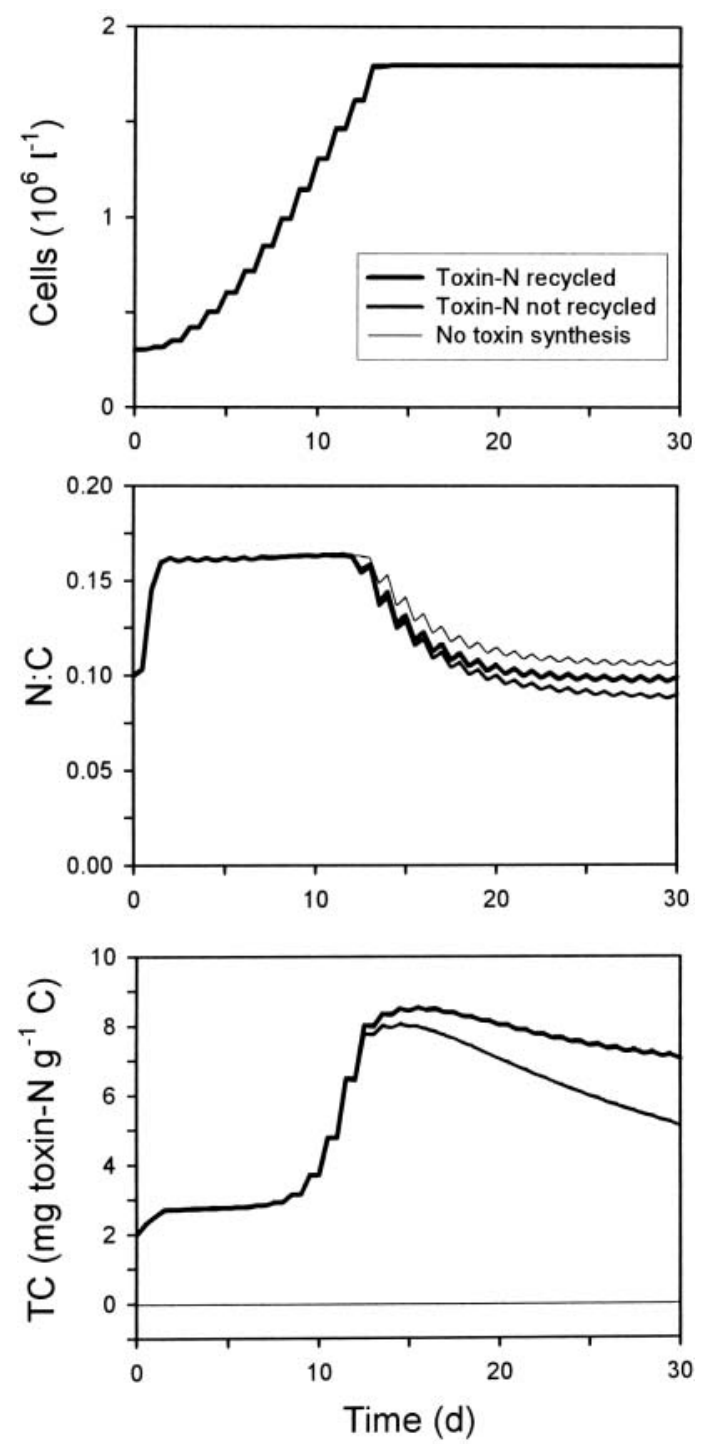

Fig. 7. Simulations generated by the model running in a nitrate-fed phosphorus-deplete scenario either with toxin synthesis and toxin recycling enabled (as in Figs 4 \& 5), with toxin synthesis enabled but with no toxin turnover (toxins being lost to the medium), or with no toxin synthesis at all mechanistic model of algal physiology to such diverse experimental data. The greatest problems arise from the fit to cells grown on low concentrations of phosphate, difficulties with the behaviour of the organisms themselves (especially the nitrate-fed phosphorusdeplete cells which adhere to the culture-vessel walls) and the deviation in the toxin content of phosphorusdeplete ammonium versus nitrate cells. Nitrate-grown cells appear more phosphorus-stressed (for a given $\mathrm{P}: \mathrm{C})$ than ammonium-grown cells of $A$. fundyense (John \& Flynn 2000a). This, with the differences in the physiological status of the cells and given that many phosphorus-deplete nitrate-fed cells were larger, may well explain why the greatest deviation in cell plots was seen for this culture in Fig. 5. It is also possible that the fate of toxins in these nitrate-fed cultures differed. If the ammonium-fed phosphorus-deplete cells did indeed void toxins, while the nitrate cells did not, then the simulated toxin content (Fig. 7) would be a much better fit to the experimental data (Fig. 5). Given that nitrate-grown cells are relatively more stressed than ammonium-grown cells, such a difference in the fate of toxin- $\mathrm{N}$ is not unreasonable.
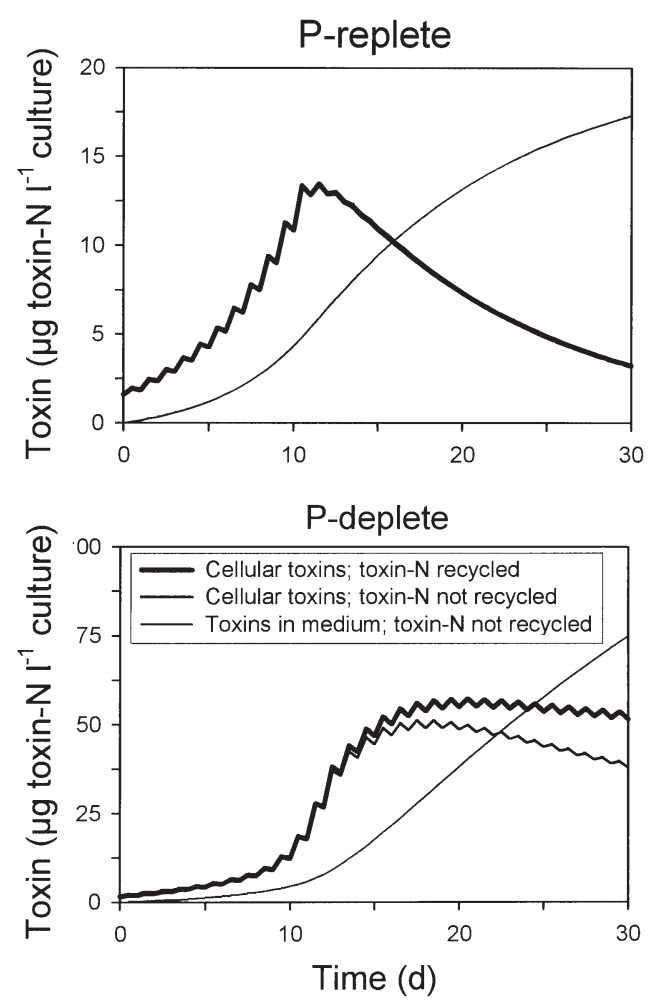

Fig. 8. Simulations generated by the model running in nitratefed phosphorus-replete and phosphorus-deplete scenarios showing the total amount of toxin in the culture either with toxin synthesis and recycling enabled (as in Figs 4 \& 5), or with toxin synthesis enabled but with no toxin turnover (toxins being lost to the medium) 
As it stands, the model is suitable for placement within ecosystem models where the activity of vegetative cells of Alexandrium spp. is important. While hydrodynamic studies indicate where cysts and cells may be transported (e.g. most recently Brown et al. 2001), models of the growth and physiology of the vegetative cells are required to extend the usefulness of hydrodynamic predictions to harmful algal bloom events. Thus the model would be of use in considering the implications of advection of Alexandrium spp. into coastal waters of different nutrient N:P content. With the parameterising of similar models for other components of the phytoplankton, interspecies competition and their implications for toxicity may also be explored. If indeed toxins do have a role in triggering encystment (Wyatt \& Jenkinson 1997), then a model that can simulate toxin development would also be of use. While the current model does not handle behavioural traits (such as vertical migration) or sexual reproduction, the structure is comprehensive enough to allow future expansion.

Application of the model to predict toxicity (as distinct from toxin content) requires a knowledge of the toxin profile and toxicities of the component toxins (Oshima 1995b). Although we have assumed a constant toxin profile (as our experimental data showed no significant shift in the composition: John \& Flynn 2000a), a simulation of a variable profile with changing nutrient status (Anderson et al. 1990b) could readily be included, assuming that the current model structure describes the change in the total toxin-N content and that a change in profile occurs due to interconversion within the total toxin load with nutrient status.

\section{Fate of toxins}

It is clear that the PSP content of cells falls, either by recycling of their components or by release from the cell. The concentration of toxins in cells can be high (low-mid mM range; Boyer et al. 1987, Anderson et al. 1990a, John \& Flynn 2000a), and so the gradient across the plasma membrane would exceed $10^{6}$. However, the toxin molecule is too large (and is also polar) to readily pass the membrane of an intact cell, thus implicating the operation of a transporter. If that porter required ATP for its operation, then phosphorus stress could adversely affect loss of toxin from the cell, leading to elevated cellular concentrations.

Some marine bacteria are reported to produce PSP, but here the toxins appear to be extracellular and are present in cultures grown in nutrient-rich conditions (Gallacher et al. 1997). The means by which toxins from bacteria accumulate in the medium (through cell lysis for example) is unclear. Similar loss of nitrogen from a phytoplankton cell, through leakage or excretion, could be seen as disadvantageous for organisms living in a nitrogen-impoverished environment, as do typically dinoflagellates. However, the model does not indicate that this would be a significant problem, since the amount of nitrogen lost through this route is low. This was so even when the model was run to simulate continuous cultures (not shown). Toxin synthesis, with any attendant loss of nitrogen from the cell, is also highest when nitrogen is not a limiting resource. While recycling of toxin- $\mathrm{N}$ may appear more logical, given that the unique structure of these toxins would not be conducive to rapid catabolism through primary biochemical processes, a role of PSP as a 'storage' nitrogen source (Boyer et al. 1987) appears unlikely. The percentage of cell-N associated with toxins is around 5 to $10 \%$ at most (and typically nearer to $2 \%$ ).

\section{Implications for the cost of toxicity}

The structure of PSPs is novel, and one may intuitively expect their synthesis to be costly and hence that it must provide the cell with an advantage. There are toxic and non-toxic strains of the same species, and indeed the level of toxicity in toxic strains is highly variable (Anderson et al. 1990a). There is, however, no clear advantage or disadvantage in being toxic with respect to growth dynamics of individual strains in culture. In nature, for toxins to be of advantage through providing an anti-predator defence, they must not kill or disable the predator (for this will benefit all phytoplankton, many of which may then outgrow the rather slow-growing dinoflagellates) but rather selectively discourage predation on the toxic cells. Again the evidence for such a mechanism remains inconclusive (Turner et al. 1998), with non-lethal effects noted (Frangoulos et al. 2000) that are not that different to effects noted with non-PSP producing diatoms (Ianora et al. 1996).

The model predicts no significant cost to the cell (in terms of nitrogen and carbon for supporting N-assimilation) in making toxins. Accepting that the model does not take into account metabolic costs other than respiration associated with normal growth processes, but with only a few percent of total cellular nitrogen being associated with toxins, how costly could the process be? If the model is correct, that there is no significant cost, then toxin production could be selectionneutral, evolution having no advantageous or disadvantageous criteria on which to select for or against synthesis. Secondary metabolites are very common in phototrophic organisms; one only has to look at the developing evidence for toxicity of diatoms hitherto 
considered 'non-toxic' to copepods (e.g. Ianora et al. 1999) to realise that the situation is not clear-cut. Many secondary metabolites are toxic to humans and/or other animals; perhaps in the wider scheme of things there is nothing particularly special about PSPs in this respect. That is not to say that PSPs do not in fact endow cells with an advantage, but that if the cost is low, then the benefit need not be strong or even present.

Acknowledgements. This work was funded by the Natural Environment Research Council (UK) through grants to K.J.F. and a studentship to E.H.J.

\section{LITERATURE CITED}

Anderson DM, Kulis DM, Sullivan JJ, Hall S, Lee C (1990a) Dynamics and physiology of saxitoxin production by the dinoflagellates Alexandrium spp. Mar Biol 104:511-524

Anderson DM, Kulis DM, Sullivan JJ, Hall S (1990b) Toxin composition variations in one isolate of the dinoflagellate Alexandrium fundeyense. Toxicon 28:885-893

Anderson DM, Kulis DM, Doucette GJ, Gallacher JC, Balech E (1994) Biogeography of toxic dinoflagellates in the genus Alexandrium from the northeastern United States and Canada. Mar Biol 120:467-478

Béchemin C, Grzebyk D, Hachame F, Hummert C, Maestrini SY (1999) Effect of different nitrogen/phosphorus nutrient ratios on the toxin content in Alexandrium minutum. Aquat Microb Ecol 20:157-165

Boyer GL, Sullivan JJ, Andersen RJ, Harrison PJ, Taylor FJR (1987) Effects of nutrient limitation on toxin production and composition in the marine dinoflagellate Protogonyaulax tamarensis. Mar Biol 96:123-128

Brown J, Fernand L, Horsburgh KJ, Hill AE, Read JW (2001) Paralytic shellfish poisoning on the east coast of the UK in relation to seasonal density-driven circulation. J Plankton Res 23:105-116

Cembella AD (1998) Ecophysiology and metabolism of paralytic shellfish toxins in marine microalgae. In: Anderson DM, Cembella AD, Hallegraeff GM (eds) Physiological ecology of harmful algal blooms. Springer-Verlag, Berlin, p 381-403

Doucette GJ, Kodama M, Franca S, Gallacher S (1998) Bacterial interactions with harmful algal bloom species: bloom ecology, toxigenesis, and cytology. In: Anderson DM, Cembella AD, Hallegraeff GM (eds) Physiological ecology of harmful algal blooms. Springer-Verlag, Berlin, p 619-647

Flynn KJ (1998a) Physiology of toxic microalgae with special emphasis on toxin production; construction of dynamic models. In: Reguera B, Blanco J, Fernández ML, Wyatt T (eds) Harmful algae. Xunta de Galicia and Intergovernmental Oceanographic Commission of UNESCO, Paris, p 315-320

Flynn KJ (1998b) Estimation of kinetic parameters for the transport of nitrate and ammonium into marine phytoplankton. Mar Ecol Prog Ser 169:13-28

Flynn KJ (2001) A mechanistic model for describing dynamic multi-nutrient, light, temperature interactions in phytoplankton. J Plankton Res 23:977-997

Flynn KJ, Flynn K (1995) Dinoflagellate physiology: nutrient stress and toxicity. In: Lassus P, Arzul G, Erard-le Denn E,
Gentien P, Marcaillou-le Baut C (eds) Harmful marine algal blooms. Lavoisier Publishing, Paris, p 541-550

Flynn KJ, Flynn K (1998) The release of nitrite by marine dinoflagellates - development of a mathematical simulation. Mar Biol 130:455-470

Flynn K, Franco JM, Fernández P, Reguera B, Zapata M, Wood G, Flynn KJ (1994) Changes in toxin content, biomass and pigments of the dinoflagellate Alexandrium minutum during nitrogen refeeding and growth into nitrogen or phosphorus stress. Mar Ecol Prog Ser 111:99-109

Flynn K, Jones KJ, Flynn KJ (1996a) Comparisons among species of Alexandrium (Dinophyceae) grown in nitrogenor phosphorus-limiting batch culture. Mar Biol 126:9-18

Flynn KJ, Flynn K, John EH, Reguera B, Reyero MI, Franco JM (1996b) Changes in toxins, intracellular and dissolved free amino acids of the toxic dinoflagellate Gymnodinium catenatum in response to changes in inorganic nutrients and salinity. J Plankton Res 18:2093-2111

Flynn KJ, Fasham MJR, Hipkin CR (1997) Modelling the interaction between ammonium and nitrate uptake in marine phytoplankton. Philos Trans R Soc Lond B Biol Sci 352:1625-1645

Flynn KJ, Page S, Wood G, Hipkin CR (1999) Variations in the maximum transport rates for ammonium and nitrate in the prymnesiophyte Emiliania huxleyi and the raphidophyte Heterosigma carterae. J Plankton Res 21:355-371

Frangoulos M, Guisande C, Maneiro I, Riveiro I, Franco J (2000) Short-term and long-term effects of the toxic dinoflagellate Alexandrium minutum on the copepod Acartia clausi. Mar Ecol Prog Ser 203:161-169

Gallacher S, Smith EA (1999) Bacteria and paralytic shellfish toxins. Protist 150:245-255

Gallacher S, Flynn KJ, Franco JM, Brueggemann EE, Hines HB (1997) Evidence for production of paralytic shellfish toxins by bacteria associated with Alexandrium spp. (Dinophyta) in culture. App Environ Microbiol 63:239-245

Haefner JW (1996) Modeling biological systems. Chapman \& Hall, New York

Harris GP (1978) Photosynthesis, productivity and growth: the physiological ecology of phytoplankton. Arch Hydrobiol Spec Issues (Ergeb Limnol) 10:1-171

Ianora A, Poulet SA, Miralto A, Grottoli R (1996) The diatom Thalassiosira rotula affects reproductive success in the copepod Acartia clausi. Mar Biol 125:279-286

Ianora A, Miralto M, Poulet SA (1999) Are diatoms good or toxic for copepods? Reply to comment by Jónasdóttir et al. Mar Ecol Prog Ser 177:305-308

John EH, Flynn KJ (2000a) Growth dynamics and toxicity of Alexandrium fundyense (Dinophyceae): the effect of changing N:P supply ratios on internal toxin and nutrient levels. Eur J Phycol 35:11-23

John EH, Flynn KJ (2000b) Modelling phosphate transport and assimilation in microalgae; how much complexity is warranted? Ecol Model 125:145-157

Jones GJ, Negri AP (1997) Persistence and degradation of cyanobacterial paralytic shellfish poisons (PSPs) in freshwaters. Water Res 31:525-533

Kaas H, Henriksen P (2000) Saxitoxins (PSP toxins) in Danish lakes. Water Res 34:2089-2097

Liu G, Janowitz GS, Kamykowski D (2001a) A biophysical model of population dynamics of the autotrophic dinoflagellate Gymnodinium breve. Mar Ecol Prog Ser 210: 101-124

Liu G, Janowitz GS, Kamykowski D (2001b) The influence of environmental nutrient conditions on Gymnodinium breve (Dinophyceae) population dynamics: a numerical study. Mar Ecol Prog Ser 213:13-37 
Ogata T, Ishimaru T, Kodama M (1987) Effect of water temperature and light intensity on growth rate and toxicity change in Protogonyaulax tamarensis. Mar Biol 95: $217-220$

Oshima Y (1995a) Chemical and enzymatic transformations of paralytic shellfish toxins in marine organisms. In: Lassus $P$, Arzul G, Erard-le Denn E, Gentien P, Marcaillou-le Baut C (eds) Harmful marine algal blooms. Lavoisier Publishing, Paris, p 475-480

Oshima Y (1995b) Postcolumn derivatization liquid chromatographic method for paralytic shellfish toxins. J AOAC Int 78:528-532

Plumley FG (1997) Marine algal toxins: biochemistry, genetics, and molecular biology. Limnol Oceanogr 42:1252-1264

Plumley FG, Wei ZY, Toivanen TB, Doucette GJ, Franca S (1999) Tn5 mutagenesis of Pseudomonas stutzeri SF/PS, a bacterium associated with Alexandrium lusitanicum (Dinophyceae) and paralytic shellfish poisoning. J Phycol 35:1390-1396

Rykiel EJ Jr (1996) Testing ecological models: the means of validation. Ecol Model 90:229-244

Editorial responsibility: Otto Kinne (Editor),

Oldendorf/Luhe, Germany
Shimizu Y (1996) Microalgal metabolites: a new perspective. Annu Rev Microbiol 50:431-465

Shimizu Y, Gupta S, Norte M, Hori A, Genenah A, Kobayashi M (1985) Biosynthesis of paralytic shellfish toxins. In: Anderson DM, White AW, Baden DG (eds) Toxic dinoflagellates. Elsevier, New York, p 271-274

Siu GKY, Young MLC, Chan DKO (1997) Environmental and nutritional factors which regulate population dynamics and toxin production in the dinoflagellate Alexandrium catenella. Hydrobiologia 352:117-140

Taroncher-Oldenburg G, Kulis DM, Anderson DM (1997) Toxin variability during the cell cycle of the dinoflagellate Alexandrium fundyense. Limnol Oceanogr 42: $1178-1188$

Turner JT, Tester PA, Hansen PJ (1998) Interactions between toxic marine phytoplankton and metazoan and protistan grazers. In: Anderson DM, Cembella AD, Hallegraeff GM (eds) Physiological ecology of harmful algal blooms. Springer-Verlag, Berlin, p 453-474

Wyatt T, Jenkinson IR (1997) Notes on Alexandrium population dynamics. J Plankton Res 19:551-575

Submitted: November 22, 2000 Accepted: May 23, 2001

Proofs received from author(s): January 8, 2002 